Tér és Társadalom 21. évf. 2007/4. 73-94. p.

\title{
AZ EURÓPAI UNIÓS FORRÁSOKHOZ KAPCSOLÓDÓ ELJÁRÁSREND HAZAI JOGI SZABÁLYOZÁSÁNAK PROBLÉMÁI
}

\author{
(Problems of the Hungarian Legal Regulation of the Procedures \\ Relating to the European Union Resources)
}

\author{
FINTA ISTVÁN
}

\begin{abstract}
Kulcsszavak:
Strukturális Alapok eljárásrend jogállamiság nyilvánosság jogorvoslat

A tanulmány a Strukturális Alapokhoz kapcsolódó eljárási kérdésekkel foglalkozik, melyek kialakitása és alkalmazása tekintetében kettős gyakorlat figyelhetö meg. Az eljárási szabályok egy részét miniszteri rendeleti szinten rendezik, a másik részét pedig a jogi szabályozás mellözésével, belsô szervezeti szabályok formájảban alakitják ki. Kétségtelen, hogy bármely állami, fejlesztési típusú cél-legyen az akár a legnemesebb - megvalósitása sokkal egyszerübb és hatékonyabb a jogi szabályozás mellözésével, ez viszont a demokratikus jogállam szükségességét kérdojelezi meg, és másfajta állami berendezkedés elemeit helyezi elötérbe.

A tanulmány az eljárásrend jogi szabályozására három eltérö megoldást lát, melyek a következök:

- A közigazgatási eljárásról szóló törvények (Áe., Ket.) hatályának kiterjesztése.

A sui generis szabályozás.

- A létezó és kialakitandó eljárási szabályok integrációja egy jelenleg is funkcionáló jogszabályba. A tanulmány külön foglakozik a pályázati támogatási forma kiegészitendö, vagy további szabályozást igényló elemeivel, valamint a jogállami müködés szempontjából olyan jelentös kérdésekkel, mint a jogorvoslati rendszer jogi szabályozása, illetöleg a nyilvánosság elvének nem megfeleló érvényesülése és beépülése a közösségi források elosztásához kapcsolódó eljárásrend jogi szabályozásába.
\end{abstract}

\section{Bevezetés}

Hazánk uniós csatlakozását követően szükségessé vált a közösségi források kezelésére, illetőleg a közösségi célokhoz igazodó nemzeti programok megvalósításához szükséges intézmény- és eljárási rend kialakítása. A források hazánk fejlődésében, gazdasági növekedésében játszott kiemelt szerepét talán nem szükséges hangsúlyozni, azt viszont igen, hogy a forrásfelhasználás hatékonysága, a célmegvalósítás eredményessége tekintetében a kialakult, vagy kialakítandó intézmény- és eljárásrend döntő szerepet játszik.

A közösségi normák az intézményrendszerre vonatkozóan ugyan tartalmaznak rendelkezéseket, ugyanakkor az egyes nemzetállamok számára meglehetősen nagy mozgásteret biztosítanak a tényleges szervezetrendszer kialakítása tekintetében.

Az eljárásrendet tekintve a közösségi jogi szabályozás elsỏdlegesen a monitoring rendszerre, a pénzmozgásra vonatkozó szabályozásra koncentrál, mely az eljárási 
rendnek - ugyan kétségtelenül fontos, de csupán - egyetlen részét, szakaszát jelenti, és korántsem öleli fel a forráselosztási folyamat egészét.

Mindebből érzékelhetö, hogy a közösségi szabályozás csupán keretjelleggel határozza meg a források felhasználásához szükséges eljárás- és intézményrendszert, ami egyúttal komoly feladatot és felelösséget hárít a nemzeti döntéshozókra a megfelelő megoldások kialakítása és fenntartása tekintetében.

A 2004-2006 közötti - hazánkat érintő - programozási időszakban a kormányzat ugyan kialakított egyfajta intézmény- és eljárásrendet, azonban - legalábbis remélhetőleg - ez sokkal inkább egy tanulási, adaptációs folyamat részeként értékelhetö, semmint kőbe vésett, egyedül üdvözítőnek tekintett megoldáshalmaznak. A 2007-2013 közötti időszakra vonatkozó jogi szabályozás kétségtelenül számos tekintetben előrelépést jelent a jogállami, illetve a klasszikus eljárásjogi normák kialakítása, adaptálása felé vezető - úgy tünik eléggé rögös - úton, azonban a jelenlegi rendszer sem tekinthető problémamentesnek. A forráselosztási rendszer jövőjére vonatkozó elképzelések és javaslatok számos problémát vizsgálva sokféle szempontból közelítik meg a lehetséges megoldásokat.

Az eljárási szabályok szempontjából az is fontos kérdés, hogy a kialakult szervezetrendszer beilleszthetö-e a magyar államigazgatás „testébe”, illetőleg a területi szintủ államigazgatási rendszer milyen szerepet tölthet be a közösségi források elosztásában. (A szervezeti státusz az eljárásrendet is meghatározhatja, hiszen bizonyos államigazgatási szervek tevékenységét egyértelmúen - ha jogszabály eltérően nem rendelkezik - a közigazgatási eljárásról szóló törvény szabályozza.)

A jogállami követelményeknek megfelelő eljárásrend kialakítása során a területi dimenzió ugyan nem játszik lényeges szerepet (az eljárások régiónként nem változhatnak), azonban az rendkívül fontos kérdés, hogy az államigazgatás világában alkalmazott általános és különös eljárási szabályok melyike és milyen mértékben vonatkozhat a forráselosztás rendszerére.

\section{A közösségi források felhasználásához kapcsolódó eljárásrend értékelése}

A közösségi forrásokhoz kapcsolódó intézményrendszer államigazgatásban történö elhelyezése, általában az intézményrendszer helyének, szerepének megítélése szempontjából kiemelkedő fontosságú az intézmények által követett eljárásrend meghatározása.

Tény, hogy a jelenleg mủködő intézményrendszer nem tipikus államigazgatási feladatokat lát el, azonban ha az általuk követett eljárásrend azonos, vagy közeli rokon vonásokat mutat az egyébként államigazgatási szervek által követett eljárásokkal, akkor semmi kétség nem merülhet fel az intézmények jogállásának, helyének megítélését illetően. Annyi már most előre bocsátható, hogy a közösségi források elosztása során alkalmazott eljárásrend közel sem nyugszik olyan kiforrott alapokon, mint például a közigazgatási eljárásról szóló szabályok, vagy más klasz- 
szikus eljárásjogok (polgári, büntető eljárásjog). A szilárd alapok mellett problémát jelent a szabályozás heterogenitása, melyben nem csupán a különbözö szintủ szabályozás, hanem az eljáráshoz kapcsolódó szervezetek státusza, államigazgatásában betöltött helye sem tünik teljesen tisztázottnak.

\section{A jelenlegi szabályozás jellemzői}

Az eljárási szabályok kialakítása és alkalmazása tekintetében jelen pillanatban kettős gyakorlat figyelhető meg. Az egyik módszer alapján az eljárási szabályok egy részét miniszteri rendeleti szinten rendezik, a másik részét pedig a jogi szabályozás mellözésével, belsö szervezeti szabályok formájában alakítják ki.

Az átfogó szabályokat 2004-2006 között a Strukturális Alapok és a Kohéziós Alap felhasználásának általános eljárási szabályairól szóló 14/2004. (VIII. 13.) TNM-GKM-FMM-FVM-PM együttes rendelet, valamint a 2007-2013 időszakban az Európai Regionális Fejlesztési Alapból, az Európai Szociális Alapból és a Kohéziós Alapból származó támogatások felhasználásának általános eljárási szabályairól szóló 16/2006. (XII. 28.) MeHVM-PM együttes rendelet tartalmazza. A részletes rendelkezések különböző ágazati rendeletek alapján (pl. 22/2004. [VI. 8.] FMMOM együttes rendelet), de nem jogszabályi formában alakulnak ki. Ezeket a szabályokat ún. kézikönyvbe foglalják (az irányító hatóság, az operatív program végrehajtásának részletes eljárási szabályait tartalmazó müködési kézikönyvbe), melyek jogszabályként viselkednek, ugyanis betartásuk mindenki - de legalábbis a pályázók - számára kötelezö. A kézikönyvet és módosításait - pl. a HEFOP - esetén az irányító hatóság vezetőjének előterjesztése alapján a foglalkoztatás-politikai és munkaügyi miniszter - az Oktatási Minisztériummal történỏ egyeztetés után - adja ki, és vonja vissza. Ez a tény kifejezetten a jogalkotás során alkalmazott módszerekre utal, noha a végeredmény mégsem egy miniszteri rendelet.

A Regionális Operatív Program esetén az Irányító Hatóság vezetője jogosult a kézikönyv jóváhagyására, ami egyúttal kifejezi az e szabályok kialakítására vonatkozó egységes gyakorlat és szabályozás hiányát, valamint arra engedne következtetni, hogy e szabályok a szervezet rendszer müködésének belső szabályzatát alkotják. A megállapítás első felét illetően a kormányzati szervek is rámutattak arra a korántsem kivánatos állapotra, mely szerint a pályázatok és a központi projektek lebonyolítása során az irányító hatóságok, valamint a közremúködö szervezetek közel harminc eltérö módszer szerint járnak el. Az egységesítésre, a legjobb gyakorlatok elterjesztésére vonatkozó törekvések - elsősorban a Közösségi Támogatási Keret Irányító Hatósága részéről - eddig legfeljebb korlátozott sikerrel jártak.

A megállapitás második fele a nem jogszabályi formában kialakított szabályok belső szabályzati jellegére utal. Amennyiben csupán bizonyos múködési szabályok rendszeréről lenne szó, akkor azok jogi szabályozására nem feltétlenül, de legalábbis nem minden esetben lenne szükség. Ugyan a vizsgálat alá vont eljárási szabályok jogrendszeren, jogágazatokon belüli elhelyezésére még nem került sor, mégis érdemes bemutatni a közigazgatási eljárásra vonatkozó egyik legelfogadottabb megkö- 
zelítést. E szerint „az államigazgatási eljárás fogalma alá tartozik az államigazgatási szervek valamennyi cselekvésének mikéntje [...] ennek három, egymással gyakran érintkező fajtáját különböztetjük meg. Ezek:

a) hatósági (külsö) eljárás, amelynek terméke az államigazgatási szerveken kívülre ható konkrét egyedi államigazgatási aktus.

b) Az államigazgatási szervek egymás közötti (belső) eljárása ... azoknak a kapcsolatoknak a formái, amelyeket az egymásnak alá-fölé rendelt, illetve mellérendeltségi viszonyban lévő államigazgatási szervek tartanak egymással mind a normatív és konkrét aktus kibocsátása, mind az egyéb államigazgatási tevékenység eredményes ellátása végett.

c) Az ügyvitel olyan, nem aktus jellegủ államigazgatási cselekményekböl áll, amelyeket egy-egy államigazgatási szerven belül végeznek mind az aktusok létrehozása, mind pedig az államigazgatási szerv egyéb cselekményei rendjének biztosítása érdekében." (Szamel-Ivancsics 1996, 4)

Az aktus kibocsátása érdekében tett igazgatási cselekmények - különböző részletezettségü és szintủ - jogi szabályozásának igénye teljesen egyértelmü a magyar jogrendszerben. Az ügyvitel, iratkezelés szabályainak többsége szintén jogszabályi formában rendezett.

A kézikönyvekben a felsorolt tevékenységek mindhárom fajtája megtalálható, jogi szabályozásra mégsem került sor. Ellenérvként ugyan megfogalmazható, hogy az érintett szervek egy része - a regionális operatív program közremüködő szervezetei - nem közigazgatási szervezetek, hiszen mindegyikük Kht. formában mủködik. Ez alapján arra a következtetésre is juthatnánk, hogy e szervezetekre az államigazgatásra vonatkozó szabályok és megállapítások nem érvényesek. Mindazonáltal nem feledkezhetünk meg arról, hogy a közigazgatási eljárásról szóló törvény bizonyos körben - kiterjeszti hatályát a kvázi közigazgatási szervekre is. $\mathrm{Ez}$ azt jelenti, hogy a nem közigazgatási szervek esetén a közigazgatási eljárási törvény alkalmazása nem tekinthetö kivételesnek. Így tehát a státusz nem lehet akadálya a megfelelő jogi szabályozás kialakításának és éppígy nem lehet kétséges a közremüködő szervezetek tevékenységének megítélése sem.

Az eljárás jelenlegi - kétszintü - szabályozási rendszere megdöbbentő hasonlóságot mutat a rendszerváltást megelőző államigazgatási, állami szervek eljárására vonatkozó jogi, vagy nem jogi szabályozással. Abban az időszakban ,inkább a kormányzati-politikai ellenôrzés vált fontossá, gyözött az állam racionalitásának elve, ezen nem annyira az ügyintézés hatékonyságaként megragadható racionalitást, mint inkább az államcélok megvalósíthatóságának racionalitását kell érteni." (Lórinzc 1999, 38) Az államcélokat abban az időszakban is a hatalmon lévő politikai erök alakitották, melyeknek a célok érvényesítésére - jogállami és jogszabályi keretek hiányában - meghatározó befolyása volt. Az 1957. évi IV. törvény megalkotása előtt a közigazgatás központi szervei lényegében diszkrecionális módon és sokban ilyen tartalommal döntötték el az ügyeket, s elmondható, hogy továbbra sem volt igazi különbség a közigazgatás „belső” és hatósági eljárásai között, csakhogy 
Az európai uniós forrásokhoz kapcsolódó eljárásrend hazai jogi szabályozásának problémái. Tér és Társadalom 21. évf. 2007/4. 73-94. p.

TÉT XXI. évf. 2007 『 4 Az európai uniós forrásokhoz ... 77

most már a belsö eljárások is hatósági eljárásnak minösülttek, a hatósági eljárások viszont egyoldalú végrehajtásnak, különösebb garanciális jogvédelem nélkül (Lörinzc 1999). Az államigazgatási eljárásra vonatkozó ötven évvel ezelötti helyzet nem különbözött jelentös mértékben a közösségi forrásokhoz kapcsolódó jelenlegi hazai szabályozástól. Kétségtelen ugyan, hogy bármely állami, fejlesztési típusú cél - legyen az akár a legnemesebb - megvalósítása sokkal egyszerübb és hatékonyabb a jogi szabályozás mellözésével, ez viszont a demokratikus jogállam szükségességét kérdőjelezi meg és egy másfajta államberendezkedés elemeit helyezi elótérbe.

Ezt jelzi, hogy a kézikönyvekben megfogalmazott szabályokat (nem jogszabályokat) a szervezetrendszer müködéséért felelős vezető hozza, illetve hagyja jóvá. Ugyan e szabályokat magukra nézve kötelezőnek tekintik, azonban saját érdekeiknek megfelelően bármikor megváltoztathatják. A saját belsó szabályaik megsértésének vagy semmilyen, vagy csupán munkajogi következményei lehetnek. Ezzel szemben a jogszabályi formába foglalt eljárásrend annak megalkotójára nézve minden esetben kötelezö, megváltoztatása szintén jogszabályban lehetséges, megsértésük esetén a jogszabály szankciókat helyezhet kilátásba, illetôleg az eljárásban érintett hivatkozhat az eljárásrend megsértésére, melynek következményei lehetnek az eljárás eredményeként született döntésekre (elutasítás, szerződéskötés stb.).

A kézikönyvek megalkotóinak tudathasadásszerü gondolkodásmódját az is tükrözi, hogy a szabályrendszer megalkotásakor a jogszabályi formát mellözik, viszont saját magukat mégis jogalkotói - olykor a legmagasabb jogalkotói - szerepkörbe helyezik. Ezt nem csupán a szabályrendszer viselkedésének jellege (mindenkire kötelező) mutatja, hanem az is, hogy olyan jogintézmények szabályozására vállalkoznak, amelyek az országgyúlés számára és a legmagasabb (törvényi) jogalkotási forma részére vannak kizárólagosan fenntartva. A kézikönyvek ugyanis meghatározzák - többek között - a csalás fogalmát is, mely büntetőjogi kategória, és jogállamban csak a legföbb jogalkotó, csak a legmagasabb jogforrási szinten rendelkezhet róla. (A vonatkozó közösségi jogszabályok csupán a csalás és más - kisebb súlyú - pénzügyi szabálytalanságok üldözését, illetőleg megelőzését kívánják meg, de nem veszik át a nemzeti kompetenciába tartozó döntések és döntéshozók szerepét.) Mindez a kézikönyvek megalkotóit nem zavarta, és - meglehetősen sajátos tartalmú - önálló tényállás kialakításától sem riadtak vissza.

\section{A jogi szabályozás indokoltsága}

A jogállam müködéséhez a jogszabályok léte nélkülözhetetlen, a jog uralma mindenkire egyformán kiterjed. A jogállam nélkülözhetetlen eleme a jogbiztonság. A jogbiztonság az állam - $\mathrm{s}$ elsősorban a jogalkotó - kötelességévé teszi annak biztosítását, hogy a jog egésze, egyes részterületei és az egyes jogszabályok is világosak, egyértelmủek, mủködésüket tekintve kiszámíthatóak és előreláthatóak legyenek a norma címzettjei számára. Vagyis a jogbiztonság nem csupán az egyes normák egyértelmüségét követeli meg, de az egyes jogintézmények müködésének kiszámithatóságát is. Ezért alapvetóek a jogbiztonság szempontjából az eljárási 
garanciák. Csak formalizált eljárás szabályainak követésével keletkezhet érvényes jogszabály, csak az eljárási normák betartásával müködnek alkotmányosan a jogintézmények (9/1992. [I. 30.] AB határozat).

A jogi szabályozás mellőzése többek között kizárja a felsőbb szintủ (pl. alkotmánybírósági) normakontrollt, nem garantálja a magyar és a közösségi jogrendszer céljainak, elveinek érvényesülését.

A közösségi források közösségi és nemzeti szinten meghatározott közcélok megvalósulását kívánják biztosítani. A közcélok megvalósulásának rendjére meglehetősen sokféle közigazgatási eljárási jogszabály született (ezek között kitüntetett szerepet tölt be hazánkban a közigazgatási eljárásról szóló törvény [Ket.], de ez „csupán” egyike a rendkívül nagyszámú és sokféle közcélhoz kapcsolódó eljárási normáknak, igaz integráló szerepe rendkívül jelentős). A német jogfelfogás szerint - azon túl, hogy a közigazgatási eljárást az államcélok konkretizálásának sajátos módjának tartja - az eljárásjog a közigazgatás törvényességének mércéje. Ettől a megközelítéstől nem áll messze az, az értelmezés, mely szerint a közigazgatási eljárásjog nem a közigazgatási szervek által teremtett, hanem az ellenörzésükre szolgáló jog (Schwartz 1976.) Mindkét felfogás kiemelt figyelmet szentel a megvalósítást szolgáló eljárásrend törvényességének és az eljárás jogvédö funkciójának.

A közigazgatási eljárásrend lényegi jellemzőire vonatkozó megállapításokat azért tünt szükségesnek felidézni, mert ugyanilyen követelmények és igények fogalmazhatók meg a közösségi források elosztására vonatkozó eljárásrenddel szemben is. Ezek a források különböző programok megvalósításának eszközei, melyek egyik talán ritkán hangoztatott - jellemzője az, hogy közösségi célokat szolgálnak, közcél érdekében hozták létre (mind uniós, mind nemzeti szinten).

A közcélok (programok) megvalósításában meghatározó szerepet játszanak a közpénzek. A közpénzek felhasználásának elengedhetetlen feltétele az átláthatóság, az ellenórizhetőség, a garanciális szabályok érvényesítése, mely jogi szabályozás nélkül elképzelhetetlen. Tisztán a jogi alapok léte sem tekinthetö elegendönek, ha a szabályozás részletezettsége, garancia rendszere nem biztositja az eljárásrend átláthatóságát.

A megfelelő jogi szabályozás kialakításának szükségességét az Unió különböző szervei több ízben is hangsúlyozták. Ennek egyik elemeként értékelhetỏ az, hogy a közösségi források felhasználásának meghatározott fázisát a közösségi jog irányelvek útján szabályozza. Az irányelv - az Európai Közösséget létrehozó szerződés 249. Cikkének (3) bekezdése szerint - az elérendó cél tekintetében valamennyi címzett tagállamot kötelezi, ugyanakkor a módszer és eszközök megválasztását a tagállami hatóságokra bízza. Az irányelvekkel kapcsolatban - a közösségi jog általános szabályai és az Európai Bíróság joggyakorlata alapján - transzpozíciós (átültetési) kötelezettség terheli a tagállamokat. A tagállamok kötelesek megtenni a szükséges jogalkotási lépéseket (és egyéb intézkedéseket) annak érdekében, hogy nemzeti jogrendszerüket összhangba hozzák az irányelvben foglalt rendelkezésekkel. Az Európai Bíróság több határozatában is állást foglalt abban a kérdésben, hogy az egyes tagállamoknak hogyan, milyen formában kell eleget tenniük joghar- 
Az európai uniós forrásokhoz kapcsolódó eljárásrend hazai jogi szabályozásának problémái. Tér és Társadalom 21. évf. 2007/4. 73-94. p.

TÉT XXI. évf. 2007 - 4 Az európai uniós forrásokhoz ... 79

monizációs kötelezettségüknek. E szerint nem megfelelő önmagában az irányelvben foglalt szabályokkal teljes mértékben összhangban álló gyakorlatra történő hivatkozás, hanem jogszabállyal át kell ültetni a hazai jogba az adott irányelv rendelkezéseit. Továbbá azt is kimondta a Bíróság, hogy az irányelvek rendelkezéseit ugyanolyan jogi kötelezỏ erövel biró jogszabályban kell a hazai jogrendszerbe illeszteni, mint amilyen szintü jogszabály korábban az adott kérdéskört szabályozta (2003. évi CXXIX. törvény magyarázata).

Az iménti megállapítások - a közpénzek felhasználásával kapcsolatosan is - rámutatnak a jogi szabályozás fontosságára még abban az esetben is, ha az adott tárgykörben létezik közösségi jogi szabályozás.

\section{A közösségi forrásokhoz kapcsolódó eljárási szabályok jogrendszeren belüli elhelyezése, a szabályozás lehetséges módszerei}

Feltételezhető, hogy a közcélokat közpénzből megvalósító eljárási szabályok a közigazgatási eljárási szabályok meglehetősen népes csoportjába sorolhatók. Az viszont korántsem egyértelmü, hogy a közösségi - sőt a hazai területfejlesztési forrásokhoz kapcsolódó eljárások szabályozása milyen módon történjék. Elvileg három lehetőség kínálkozik e kérdés megválaszolására. Az első megoldás szerint az eljárási rendre a közigazgatási hatósági eljárás és szolgáltatás általános szabályairól szóló törvény szabályait kellene alkalmazni. A második lehetőség az önálló, sui generis jogi szabályozás kialakítása (melyet a jelenlegi gyakorlat leginkább követni látszik). A harmadik lehetőség egy olyan jogszabályba történő integrációt jelent, amelynek szabályozási tárgyköre, igénye és megoldásai hasonlóak, illetőleg csaknem megegyezök a vizsgált terület szabályaival. A továbbiakban a három szabályozási módszer mellett, illetve ellen szóló érvek rövid bemutatására kerül sor.

A közigazgatási eljárásról szóló törvények (Áe., Ket.) és az egyéb állami célok megvalósulását szolgáló eljárási szabályok viszonya

A kilencvenes években - különösen az évtized második felében - a közigazgatási eljárás általános szabályainak egyre jelentősebb fellazulásának lehetünk tanúi. Az általános szabályok mellett speciális - adott esetben akár rendeleti - eljárási szabályok is létezhetnek, ezekkel szemben viszont elvárás, hogy összhangban álljanak az általános szabályokkal, illetve azok keretei között érvényesüljenek. Az utóbbi években viszont a jogalkotás egyre inkább teret enged azoknak az ágazati érdekeknek, amelyek az adott eljárási körben az általános szabályoktól való eltéréseket, specialitásokat tették főszabállyá. Mindez történik annak érdemi vizsgálata nélkül, hogy valóban fennálnak-e az eltérés indokai. Csökkent az a szigorúság is, amellyel a rendeleti jogot az eljárási törvényhez kell igazítani (Mónus 1997; Berényi 1998).

A jelenleg hatályos közigazgatási eljárási törvény saját tárgyi hatályának megállapításánál az eljárásfajtákat három kategóriába sorolja. Az első kategóriába tartozó eljárásokat eleve kiveszi saját hatálya alól. A második kategóriába sorolt eljárásokra 
ugyan elvileg kiterjedt a törvény hatálya, ám rendelkezéseit csak akkor kellett alkalmazni, „ha jogszabály másként nem rendelkezik”. Ez gyakorlatilag azt jelenti, hogy akár miniszteri rendelet is „félreteheti” a törvény bármelyik rendelkezését. Végül a harmadik kategóriába tartozik az összes többi eljárásfajta, azaz az eljárásfajták túlnyomó többsége. Összességében tehát a törvény - amellett, hogy garanciális szabályokat állapít meg - bőséges mozgásteret biztosít a különös eljárási szabályok számára ahhoz, hogy azok megfelelően érvényre juttathassák a különböző közigazgatási eljárásfajták sajảtosságait. Mindez értékelhető pozitívan, ha cél a kormányzati végrehajtási rendszer szabályozási igényeinek megfelelő akadálymentesítés, és értékelhető kevésbé pozitívan, ha a törvényi szabályozás átfogó, általános és kógens funkciójára gondolunk.

Az mindenesetre kétségtelen, hogy a Ket. elsősorban a hatósági típusú ügyek intézését kívánja rendezni. Ugyanakkor tény az, hogy az állam, illetőleg az önkormányzatok, vagy más szervezetek által ellátott közfeladatok jelentős része nem igényel semmilyen hatósági típusú cselekményt. (A Ket. éppen a nem hatósági eljárás egyes nevesített fajtáit veszi ki hatálya alól.) A területfejlesztési célok megvalósítása során hozott döntések szintén nem tekinthetők hatósági határozatoknak, így a Ket. kevéssé tủnik alkalmasnak arra, hogy az e területet jellemző eljárásokat megfelelöen kezelje. Természetesen egyes szabályai - pl. alapelvek, jogorvoslati rendszer stb. - bizonyos eltéréssel alkalmazhatók, sőt alkalmazandók a közösségi források, illetőleg a hazai területfejlesztési forrásokra vonatkozó eljárásrend szabályozása során.

\section{A sui generis szabályozás}

Hazánkban pillanatnyilag a jogalkotó a közösségi forrásokhoz kapcsolódó eljárási szabályokat önállóan, miniszteri rendeleti szinten rendezi. Az általános szabályokról szóló 14/2004. (VIII. 13.) TNM-GKM-FMM-FVM-PM, valamint a 16/2006. (XII. 28.) MeHVM-PM együttes rendelet megalkotása Magyarországon dicséretes tény, mindazonáltal nem tünik teljesen alkalmasnak a pártatlan, befolyástól mentes döntéshozatali mechanizmus garantálására. A jogszabályban nem szerepelnek, vagy nem megfelelő szabályozottsági szinten szerepelnek olyan - a fenti cél szolgálatában álló és a későbbiekben részletezendő - elemek, amelyek a klasszikus eljảrásjogok nélkülözhetetlen tényezői közé sorolhatók. Mindez természetesen nem a szabályozási módszert, az az a sui generis szabályozást minősíti, hiszen egyetlen megfelelöen kidolgozott jogszabály is kielégitően biztosíthatja a célok megvalósulásának kereteit, valamint az eljárással szemben támasztott általános társadalmi és speciális jogtudományi elvárásokat.

A közösségi forrásokhoz kapcsolódó eljárási formák elegendően speciálisak és fontosak ahhoz, hogy - ilyen típusú jogalkotói döntés esetén - megalapozzák egy megfelelö szintü, önálló jogszabály megalkotását. Ugyanakkor szükséges hangsúlyozni, hogy ebben az esetben is tiszteletben kell tartani és meg kell teremteni az összhangot a Ket. általános elveivel és szabályrendszerével. 
Az európai uniós forrásokhoz kapcsolódó eljárásrend hazai jogi szabályozásának problémái. Tér és Társadalom 21. évf. 2007/4. 73-94. p.

TÉT XXI. évf. 2007 - 4 Az európai uniós forrásokhoz ...

Ezt a filozófiát látszik megerỏsíteni a nemzetgazdasági szempontból kiemelt jelentöségü beruházások megvalósitásának gyorsításáról és egyszerüsitéséröl szóló 2006. évi LIII. törvény, amely - a Ket. általános rendelkezéseinek tiszteletben tartása mellett - önálló, speciális szabályokat állapít meg egyes közösségi forrásból megvalósuló beruházásokkal kapcsolatos közigazgatási hatósági ügyek intézésére vonatkozóan. A jogalkotó felismerte a területi közigazgatási szerveknek az egyes programok megvalósíthatóságában betöltött kiemelkedö szerepét. A jogszabály ugyan alapvetơen a hatósági eljárásokról szól (a különböző engedélyek nélkülözhetetlen elemei a beruházás megvalósításának, de olykor a forráselosztásról szóló döntéseknek is), azonban nem csupán a megvalósitáshoz kapcsolódó különleges nemzeti érdeket veszi figyelembe, hanem a közösségi források elosztásához, felhasználásához kapcsolódó speciális eljárási szabályozási igényt is, melynek a jelzett törvény formájában kíván eleget tenni.

A létezö és kialakitandó eljárási szabályok integrációja egy jelenleg is funkcionáló jogszabályba

Az önálló jogszabályalkotás mellett felmerülhet annak a lehetősége is, hogy egy meglévő, hasonló tárgyú és célú jogszabály kiegészítése, valamint szükségszerü módosítása mellett történjen meg a közösségi forrásokhoz kapcsolódó eljárásrend megfelelö jogszabályi rendezése. Erre a közbeszerzésekröl szóló 2003. évi CXXIX. törvény nyújthat lehetőséget.

A teljes érthetỏség kedvéért meg kell különböztetni a közösségi források elosztásának két szakaszát. Az elsó szakaszban történik azon támogatottak (pályázati forma esetén nyertes pályázók) kiválasztása, akik a kiírásnak megfelelő célok megvalósítására leginkább érdemesnek mutatkoznak. Ök nevezhetök magyar értelemben nem uniós szóhasználat szerint - kedvezményezetteknek. A második szakaszban történik a konkrét kivitelezés, ami egy építés, beszerzés vagy szolgáltatás megvalósítását jelenti. (Az első szakasz pályázatának nyertese az uniós normák szerint nem lehet egyben kivitelezó, megvalósító szervezet is.) A közbeszerzési törvény a pályáztatás ezen második szakaszát szabályozza, tehát azt kívánja megállapítani, hogy a megvalósításra mely vállalkozás a legalkalmasabb. A megvalósitó szervezetre vonatkozóan tehát létezik egy magas szintü, EU konform törvényi szabályozás, mig a kedvezményezetté válás folyamatát - vagyis, hogy ki kapja a pénzt - egy meglehetösen hiányos miniszteri szintü rendelet (a 14/2004. [VIII. 13.] TNM-GKM-FMM-FVMPM, valamint a 16/2006. [XII. 28.] MeHVM-PM egyittes rendelet) hivatott rendezni.

Szükséges azt is megjegyezni, hogy míg a közbeszerzési rendszer szabályozását az Európai Unió - irányelvei és a Bíróság határozatai segítségével - „kikényszerítette", addig az elsó fózisra vonatkozóan a közösség semmilyen jogszabályi formában nem határozott meg eljárási rendelkezéseket. A forráselosztásra tehát csak nemzeti szintü szabályozás létezik, míg a forrásfelhasználásra közösségi és nemzeti (törvényi szintü) szabályozás született. Igaz ugyan, hogy a közbeszerzési 
szabályok nem csupán a közösségi forrásokból származó pénzeszközökre érvényesek, de a jogszabályi rendezés indokai mindkét esetben azonosnak tekinthetök.

Amilyen szoros összefüggést mutat a közcél és a megvalósításához szükséges közpénz közötti viszony, logikailag éppoly szorosan kapcsolódik egymáshoz a forráselosztás és a forrásfelhasználás szabályrendszere.

A közbeszerzési törvény megalkotásának indokait a jogalkotó a következőkben jelölte meg:

- a közpénzek ésszerü felhasználása,

- az átláthatóság és széles körủ nyilvános ellenörizhetőség megteremtése,

- továbbá a közbeszerzések során a verseny tisztaságának biztosítása.

A közösségi forrásokra (pontosabban azok elosztására) vonatkozó szabályozás indokai sem különbözhetnek a közbeszerzési törvényben meghatározott céloktól, igaz a verseny tisztaságát itt nem csupán a vállalkozások, profit szféra világában kellene biztosítani, hanem a kedvezményezettek között jelentős szerepet játszó közés nonprofit szereplök között is. A közbeszerzési törvény indoklása szerint - mely teljesen érvényesnek tekinthető a közösségi forrásokhoz kötődő eljárási szabályok megalkotása során is - a törvény megalkotása és felülvizsgálata nem öncél, hiszen legalább ilyen fontos cél a közpénzfelhasználás átláthatóságának, nyilvánosságának erősítése, és ezen keresztül annak kifejezésre juttatása, hogy az állam elkötelezett az állami pénzekkel való visszaélés, a korrupt magatartások visszaszorítása és megelőzése érdekében. Az állami megrendelések megszerzése - éppúgy, ahogy a közösségi források elnyerése - nagy vonzerövel bír, tekintettel arra, hogy a piaci szereplök számára ezek biztos megrendeléseket jelentenek. A közösségi források megszerzése - különösen a közszférában - alkalmas lehet politikai tóke kovácsolására. Ezzel is magyarázható, hogy a piaci szereplök - vélhetően nem csak ök - gyakran válnak korrupt magatartások célpontjaivá. Ugyanakkor az sem hagyható figyelmen kívül, hogy a közbeszerzési törvény létének, az általa biztosított átláthatóságnak és nyilvánosságnak is köszönhető, hogy ezek az esetleges visszaélések, összejátszások egyáltalán ismertté válhatnak. A Kbt. hatályba lépése előtt a közpénzek elköltését a társadalmi kontroll szempontjából homály fedte. A korrupció elleni küzdelem leghatékonyabb módja e területen a közbeszerzési jogszabályok betartásának kikényszerítése, következetes érvényre juttatása. Az iménti megállapítások - okok, következmények és megoldások - vélhetően ugyanígy érvényesnek tekinthetők a forráselosztáshoz kapcsolódó eljárásra nézve is.

Mind a forráselosztás, mind pedig a forrásfelhasználás egyik legfontosabb eljárási formája a pályázati rendszer. Ez az azonosság ismét felhívja a figyelmet a két szabályozási rendszer közötti szoros összefüggésre, az esetleges egy jogszabályon belüli rendezés lehetőségére. Természetes, hogy a forráselosztás és a forrásfelhasználás részletszabályai egymástól olykor jelentősen eltérö rendezést is igényelhetnek, azonban a közös célok és a közbeszerzési törvényben már meghonosított garanciális és egyéb szabályok egyszerúbbé tehetik a jogszabály kialakítását. Ugyanakkor - 
Az európai uniós forrásokhoz kapcsolódó eljárásrend hazai jogi szabályozásának problémái. Tér és Társadalom 21. évf. 2007/4. 73-94. p.

TÉT XXI. évf. 2007 a 4

Az európai uniós forrásokhoz ...

önálló szabályozás esetén - lehetséges az ezen szabályokra történő hivatkozás, vagy átemelésük a különálló jogszabályba.

A különbségek elismerése mellett - függetlenül attól, hogy önálló vagy integrált szabályozásra kerül sor - egy kérdésben egyértelmú állásfoglalás alakítható ki. Ez a kérdés a szabályozás szintje, mely semmiképp nem lehet alacsonyabb, mint amilyen formában a közbeszerzések szabályozása megvalósul. Az Európai Unió kohéziós politikája és az ahhoz kapcsolódó Strukturális Alapokból származó források valószínủleg hosszabb távon, de - reményeink szerint - legalább 2013-ig hazánk rendelkezésére állnak. Nehezen magyarázható, hogy ilyen hosszú időszakon keresztül, az ország fejlődése szempontjából ilyen jelentős terület szabályozása gyakran változó és változtatható kormányzati, ágazati rendelet formájában valósuljon meg. Arra is nehezen lehetne elfogadható érvet találni, ami azt bizonyítaná, hogy a forráselosztás alacsonyabb rendủ és törvényi szabályozásához csekélyebb társadalmi érdek füződik, mint a forrásfelhasználás szabályozásához.

\section{A jogi szabályozás felülvizsgálandó, kiegészítendö elemei}

A továbbiakban azokra a szabályozási elemeknek a bemutatására, elemzésére kerül sor, amelyeknek - álláspontunk szerint - mindenképpen szerepelnie kell a közösségi forrásokhoz kapcsolódó eljárásrendet tartalmazó jogszabályban. A vizsgálat alapját a Strukturális Alapok és a Kohéziós Alap felhasználásának általános eljárási szabályairól szóló 14/2004. (VIII. 13.) TNM-GKM-FMM-FVM-PM, valamint a 16/2006. (XII. 28.) MeHVM-PM együttes rendelet, a közbeszerzésekröl szóló 2003. évi CXXIX. törvény, valamint a közigazgatási hatósági eljárás és szolgáltatás általános szabályairól szóló 2004. évi CXL. törvény képezi. A négy jogszabály közül az elsö kettö kitüntetett helyzetü, amit az jelez, hogy a jogszabályokban szereplö azon rendelkezések, amelyekröl a továbbiakban nem esik szó - vizsgálódásunk szempontjai alapján nem szorulnak módositásra, kiegészitésre, az alábbiakban ismertetendő lehetséges szabályozási elemek viszont részei lehetnek a jelenleg hatályos, illetỏleg a jövőben megalkotandó törvényi szintủ szabályozásnak.

\section{Az alapelvek}

Kidolgozott és magas szintủ jogi normák esetén az alapelvekröl történő rendelkezés napjainkban a norma nélkülözhetetlen eleme.

A mintaértékủ közbeszerzési törvény indoklása az eljárási alapelveknek kettős szerepet tulajdonít. Eszerint az alapelvek egyrészt meghatározzák a közbeszerzési eljárás egész menetét, és az egyes részletszabályokban tételesen is megfogalmazódnak, a konkrét normákat elvi háttérrel övezik. Másrészt a jogalkalmazók számára iránymutatásul is szolgálnak egyes konkrét normák értelmezésénél, vagy valamely - a törvényben nem szabályozott - részletkérdés esetén követendő megoldás tekintetében. A közbeszerzési törvény gyakorlati alkalmazása során - csakúgy, mint a közösségi forrásokról szóló döntések kapcsán - gyakran alakulhatnak ki olyan 
helyzetek, amelyeket a jogszabály elökészítése, megalkotása során nem lehetett elöre látni és így azokra nézve szabályt sem lehetett alkotni.

Az alapelvek jelentőségét az is növeli, hogy azok - legalábbis a közbeszerzések esetén - generálklauzulaként is müködnek. Ezen elvekbe bármilyen formában ütközö eljárási cselekmények esetén - külön tiltó rendelkezések hiányában is - jogorvoslati eljárást lehet kezdeményezni a Közbeszerzési Döntöbizottság elött.

A közbeszerzési eljárás a közösségi forrásokhoz kapcsolódó eljárásrend szabályozása kapcsán alkalmazható alapelvei a következök lehetnek:

- a (pályázati) verseny tisztasága,

- a nyilvánosság,

- a támogatást igénylök (pályázók) esélyegyenlőségének biztosítása.

A Ket. által szabályozott alapelvekböl az alábbiak hasznosithatók a szabályozás során:

- a jóhiszemủ eljárás kötelezettsége, vélelme és megsértője elleni szankciók foganatosítása,

- a jogokról, kötelezettségekről történő tájékoztatás alapelve,

- a gyors, hatékony és költségtakarékos eljárás biztosításának elve.

Az eljárási alapelvek megfogalmazása során figyelembe kell venni, sőt amennyiben lehetséges át kell ültetni azokat az alapelveket, amelyek e területre vonatkozó közösségi szintü szabályozásban érvényesülnek. Ezeket az alapelveket a 2004-ben elkészített 3. kohéziós jelentés a következőkben látja:

- „Az 1988-as reform óta a programozás, a partnerség, a koncentrálás és az addicionalitás jelentik a Strukturális Alapok alapelveit." (Új partnerség... 2004)

- „Az 1988-as reform során a programozást, partnerségek alakítását, koncentrálást és az addicionalitást jelölték meg a Strukturális Alapok egységes elveiként, és ezek maradtak az Alapok hatékonyságának és a befolyásának növelését célzó irányítás kulcsfogalmai. Sokféle irányítási gyakorlat alakult ki, amelyek tiszteletben tartják a központi alapelveket, de figyelembe veszik az egyes tagállamok intézményi kontextusát és adminisztratív kapacitását, amelyek az idők során maguk is változnak." (Új partnerség... 2004, 163)

A Strukturális Alapokra vonatkozóan természetesen további alapelveket is megállapítanak a jelenleg hatályos, illetőleg a következö programozási időszakra vonatkozó rendeletek ( $\mathrm{pl}$. nemek közötti egyenlöség biztosítása stb.), amelyekre figyelemmel kell lenni, azonban a regionális politika, a területfejlesztés, a közösségi források elosztása szempontjából kiemelkedő jelentőséggel a fenti alapelvek rendelkeznek. Ez a tény önmagában megalapozza azt az elvárást, hogy a fenti alapelveket az eljárásrend kialakítása során is tiszteletben tartsák és érvényesítsék. 
Az európai uniós forrásokhoz kapcsolódó eljárásrend hazai jogi szabályozásának problémái. Tér és Társadalom 21. évf. 2007/4. 73-94. p.

TÉT XXI. évf. 2007 - 4

Az európai uniós forrásokhoz ... 85

\section{A forráselosztás formáinak meghatározása}

Az eljárásrendet rögzítő jogszabályban feltétlenül kívánatos meghatározni azokat a formákat, kereteket, valamint azok alkalmazhatóságának feltételeit és részletszabályait, amelyek a közösségi (esetleg hazai) források elosztásának alapjait képezik.

A 2004-2006 közötti időszakhoz képest jelentős előrelépést hozott a 2007-2013 programozási időszakban az Európai Regionális Fejlesztési Alapból, az Európai Szociális Alapból és a Kohéziós Alapból származó támogatások felhasználásának alapvető szabályairól és felelős intézményeiről szóló 255/2006. (XII. 8.) kormányrendelet. Az eljárásrendet ugyan a 16/2006. (XII. 28.) MeHVM-PM együttes rendelet határozza meg, azonban az eljárás szempontjából fontos alapfogalmak az elóbbi jogszabályban találhatók. A jogszabály ismeri az egyfordulós pályázatot (amelynek során kizárólag részletes projekt-javaslat kerül benyújtásra), a kétfordulós pályázatot (először előzetes projekt-javaslat, majd - amennyiben az alapján indokolt a részletes kidolgozás - részletes projekt-javaslat kerül benyújtásra), a kiemelt projektet (a kormány által egyedileg, pályáztatás nélkül jóváhagyott projekt, amelyet az akcióterv nevesítve tartalmaz), valamint a projektet, amely egy önálló fejlesztés, vagy több hasonló célú, egyenként 10 millió forintnál vagy az akciótervben meghatározott ettől eltérỏ összegnél nem nagyobb összköltségủ fejlesztés megvalósitását célzó támogatási alap (közvetett támogatás), illetőleg hasonló célú fejlesztések megvalósítását célzó hitel, tőke vagy garancia eszköz.

Az egyes fogalmakhoz kapcsolódó konkrét eljárási szabályok eltéröen alakulnak.

A pályázati rendszer kívánatos szabályozási elemei

A pályázatok különösen fontos szerepet játszanak a Strukturális Alapok céljainak megvalósitásában, hiszen egyrészt ez a támogatások biztositásának egyik legfontosabb formája, másrészt a pályázatok tartalma és követelményrendszere alapján mérhető, hogy a tervezés során meghatározott célok, valamint alapelvek gyakorlati megvalósítására mutatkozik-e igény, vagy a pályázatok ad hoc jellegủek, nem a programozási tevékenységre építő célok megvalósítását szolgálják. A tervezés és célmegvalósítás kiinduló pontja a tagállam, illetve a közösség által elfogadott tervdokumentum (NFT, KTK, ÚMFT, NSRK), amelyben a célkitüzések meglehetösen általános megfogalmazásban szerepelnek. A dokumentumokban meghatározott célok megvalósulása elött az utolsó, illetve utolsó elötti pontot az általános célok konkretizálását jelentô programok vagy projektek képezik, amelyek alakulására a pályázati kírás döntỏ befolyást gyakorol. Ez egyúttal azt is jelenti, hogy a pályázati kiírás, majd pedig - jó esetben a kiírás alapján születő - döntés együttesen képes bemutatni, hogy az általános célok és a közösségi alapelvek a gyakorlatban miként valósulhatnak meg.

A pályázatok a közpénzek elosztásának, továbbá az állami irányítás, a társadalmi, gazdasági életbe történỏ beavatkozás egyik - rendkívül fontos - formáját képviselik, ezért jogállamban nem kerülhetó meg a pályázatokra vonatkozó megfelelő 
szintü és tartalmú jogi szabályozás kialakítása. Ugyanakkor a közösségi forrásokhoz kötődő pályázati rendszerre vonatkozó jogi szabályozás napjainkban rendkívül hiányosnak tekinthetö.

Továbbiakban elsöként az elvekre - ha úgy tetszik potenciális, vagy tényleges anyagi jogi normákra - vonatkozó megállapítások bemutatására kerül sor, majd pedig a pályáztatás eljárási kérdéseiröl esik szó.

\section{A pályázati dokumentáció elkészitése}

A pályázatok kidolgozására a jelenleg hatályos szabályozás semmilyen rendelkezést nem tartalmaz. Egyedül a végeredménnyel - a pályázattal - kapcsolatosan állapít meg néhány formainak tekinthető kritériumot. Ugyanakkor nem esik szó a pályázati dokumentáció tartalmával szemben támasztott követelményekröl. A pályázat minősége az egész eljárás sikerességének alapja. A jól kidolgozott pályázati dokumentáció elősegíti a pályázatok gyors elkészitését, megkönnyíti az értékelést, egyszóval hozzájárul az egész eljárás hatékony müködtetéséhez. A tapasztalatok szerint gyakran problémát okoz a pályázatokban szereplö kifejezések, meghatározások, igények értelmezése. A pályázati dokumentációk megfogalmazása gyakran nem kellően egyértelmü, többféle értelmezésre ad lehetőséget, illetöleg túlságosan általános. Ez az állapot lehetőséget nyújt az értékelő számára, hogy a kiírást saját szempontjai, vagy más szempontok szerint értelmezze, illetve újraértelmezze. Olyan esetre is volt példa, hogy egy több projektböl álló program egyes elemeire az értékelö úgy nyilatkozott, hogy azok nem tartoznak a támogatható tevékenységek közé, viszont az adott projektek céljai és tevékenységei nem szerepeltek azon a listán, amelyen a nem támogatható tevékenységeket felsorolták.

A pályázati dokumentációban meghatározott - és a pályázót kötelezö - határidök megjelölése szintén jelentős befolyást gyakorolhat a pályázat elkészítésére. $\mathrm{Ha}$ a meghirdetés és a beadási határidő közötti időszak nagyon rövid, akkor a jelentősebb programok elkészitésének lehetősége csekély, illetőleg minőségük nem éri el a megkívánt szintet. (A 2007-2013 közötti időszakra vonatkozó eljárási szabályok a minimális időtartamot 30 napban határozták meg.) Így a jelentősebb és a területi folyamatokra érdemi hatást gyakorló programok hátrányba kerülhetnek a kevésbé fontos célokat tartalmazó, de egyszerübb helyi projektekhez képest. Ez a probléma különösen a folyamatos beadású pályázatok esetén válhat jelentössé a rendelkezésre álló keret gyors kimerítésének veszélye miatt.

A pályázati dokumentációkkal szemben megfogalmazható kritikai megjegyzések sora folytatható lenne (biztosítékok köre, az értékelést kevéssé befolyásoló mellékletek száma, általában a pályázat bonyolultsága stb.), mindez viszont már átvezet a pályázati dokumentációt elkészítő szervvel szemben támasztott alkalmassági feltételek területére. Az mindenesetre leszögezhető, hogy a kizárólag „íróasztal mellöl” megírt pályázati felhívások életképességét és alkalmazhatóságát a gyakorlat számos esetben megkérdőjelezi. A pályázat megalkotójának tisztában kell lennie a projekt megvalósításának körülményeivel, akár területi egységenként eltérő sajátosságaival, 
a potenciális kedvezményezettek helyzetével, általános múködési jellemzőivel stb. Mindezen követelmények meghatározására, a teljesítés értékelésére a közbeszerzési pályázat alkalmat nyújthat. Ezért a jogszabályban csupán - vagy legalább - azt szükséges rögzíteni, hogy a pályázati dokumentációt kidolgozó szerv kiválasztása közbeszerzés útján történik. (Persze a jogszabály meghatározhat a kidolgozóval szemben további követelményeket, ha garanciális szempontok - vagy tapasztalatok - alapján ez indokolt.)

Természetesen az absztrakt jogi szabályozás nem lehet képes minden egyes individuális probléma kezelésére, viszont a jogszabályi követelmények megfogalmazása és betartása elösegítheti a problémák kialakulásának megelőzését. Ezért a szabályozásban célszerü kifejezésre juttatni a pályázati dokumentációval szemben megfogalmazható követelményeket, melynek értelmében a pályázat megfogalmazásának és követelményrendszerének

- egzaktnak,

- számszerüsíthetőnek,

- (de legalább) mérhetönek,

- vagy összehasonlíthatónak kell lennie.

Ahol több értelmezés is felmerül, a kiírónak a legrövidebb időn belül meg kell határoznia azt a jelentéstartalmat, vagy értelmezési összefüggésrendszert, amely a pályázók számára irányadó.

\section{A nyilvánosság biztositása, az irat betekintési jog}

A 2004-2006 közötti időszak jogszabály-nyilvánosságra vonatkozó rendelkezései legfeljebb egy marketing szemléletü PR tevékenység szabályozásának minősíthetők. A 14/2004. (VIII. 13.) TNM-GKM-FMM-FVM-PM együttes rendelet egyáltalán nem rendelkezik az irat betekintési jogról. A közremüködő szervezetek és az irányító hatóság müködéséről szerzett tapasztalatok azt mutatják, hogy e szervek munkájukat a lehető legnagyobb titkolózás közepette végzik, lehetőség szerint semmiről semmilyen felvilágosítást nem adnak. Szükséges megjegyezni, hogy a nyilvánosság, illetőleg az érintett fél tájékozódási, irat betekintési jogának teljes kizárását egyetlen eljárásjog sem ismeri. (Büntetőeljárásban is legfeljebb a nyomozati szakban kerülhet erre sor.) Arra is szükséges felhívni a figyelmet, hogy ennek az eljárásnak - csakúgy, mint a közbeszerzési eljárásnak - egyik legfontosabb alapelvét a nyilvánosság elve kell, hogy jelentse. Ennek megfelelöen valamilyen körben mindenképpen rendezni szükséges ezt a kérdést.

Ezt az igényt vélhetően akceptálta a 2007-2013 közötti időszakra vonatkozó jogi szabályozás, amikor lehetővé tette, hogy a döntésről történő tájékoztatást követően a projektgazda a projekt-javaslatra vonatkozóan az értékelö lapban és az emlékeztetőben foglaltakat megismerhesse. Ez ugyan jelentős lépés a nyilvánosság elvének érvényesítése során, azonban szükséges rámutatni, hogy a szabályozás ilyen jogosultságot csak a projektgazda tekintetében és csakis a saját projekt-javaslatára hatá- 
roz meg. A döntés elfogadottsága és ezzel együtt a nyilvánosság elve teljesebben érvényesülhetne, ha valamennyi egymással versenyben lévő projektgazda (pályázó) megtekinthetné a döntés alapját képezö összes értékelést. A közbeszerzésekröl szóló törvény például - az átláthatóság, a nyilvánosság biztositása érdekében meglehetösen liberális szabályozási rendszert honosított meg, amelyben az érintettek az eljárás bármely szakaszában keletkezett iratokba, külön engedély nélkül betekinthetnek. Ennek kizárására vagy korlátozására csak akkor van lehetőség, ha a megtekinteni kívánt dokumentumok nem minösülnek közérdekủ adatnak vagy közérdekből nyilvános adatnak, megismerésük hiánya nem akadályozza az ellenérdekủ ügyfelet jogorvoslati jogának gyakorlásában, ugyanakkor az iratok vagy adatok mások általi megismerése aránytalanul súlyosan sértené az ügyfél üzleti érdekeit.

Bizonyos értelemben a nyilvánosság felé nyitást jelenti az a rendelkezés, mely a bíráló bizottság tagjai között nem csupán a központi közigazgatási és a közremüködỏ szerezetek által delegált személyeknek ad helyet, hanem lehetővé teszi egy civil szervezet által delegált személy részvételét is. Ha nem is túl jelentősen, de ez mindenképpen a nyilvánosság elvének érvényesülését segíti elö.

\section{Szakértökre, szakértelemre vonatkozó rendelkezések}

A jelenleg hatályos szabályozás több ízben tartalmaz általános rendelkezéseket a szakértelemre vonatkozóan, mely pénzügyi, jogi és az intézkedések céljainak, tartalmának megfelelő ismereteket jelent. Kérdés, hogy az ilyen általános megfogalmazás biztosíthatja-e azt, hogy az adott döntéseket a legmegfelelőbb személyek hozzák. A területfejlesztés intézményrendszere mellett, illetőleg abban nem alakult ki külön jogszabály által intézményesített szakértő hálózat. Ilyen célú kormányzati kezdeményezés ugyan 2004-ben érzékelhető volt, azonban a megalkotott jogszabályt - a terület- és regionális fejlesztési szakterületen kifejtett szakértői tevékenység szabályozásáról szóló 13/2004. (VIII. 6.) TNM rendeletet - a 30/2005. (IX. 2.) TNM rendelet hatályon kívül helyezte.

Ezzel szemben a közbeszerzési törvény a közbeszerzési eljárások szakszerüségének biztosítása, fokozása érdekében kötelezővé tette a közösségi értékhatárt elérő vagy meghaladó értékủ - bármilyen tárgyú - közbeszerzés esetében a Közbeszerzések Tanácsa által vezetett névjegyzéken szereplö hivatalos közbeszerzési tanácsadónak a közbeszerzési eljárásba történő bevonását. A törvény célja e kötelezettség elöírásával annak biztosítása, hogy a nagyobb értékủ közbeszerzéseknél a szakszerủség biztosítása érdekében az ajánlatkérőt egy - az ajánlatkérỏ szervezettől - független, elsősorban a közbeszerzés tárgya szerinti alapos szakmai ismeretekkel rendelkező személy (szervezet) segítse. A törvény alapján a független, hivatalos közbeszerzési tanácsadó feladata a közbeszerzési eljárás jogszabályoknak megfelelő lefolytatásának elősegítése, így különösen a felhívás és a dokumentáció elkészítésében kell közremúködnie, továbbá az ajánlatkérő bevonhatja a bíráló bizottságba is. A törvény egyértelmüvé teszi azt is, hogy a közbeszerzési tanácsadó tevékenységét nem „felelőtlenül” végzi: a polgári jog általános szabályai szerint felel a tevékeny- 
Az európai uniós forrásokhoz kapcsolódó eljárásrend hazai jogi szabályozásának problémái. Tér és Társadalom 21. évf. 2007/4. 73-94. p.

TÉT XXI. évf. 2007 『 4 Az európai uniós forrásokhoz ... 89

sége által okozott kárért. A hivatalos közbeszerzési tanácsadók különbözö szakmák képviselői közül kerülhetnek ki, így különböző szakterületek szakértői. A törvény minden esetben az ajánlatkéröre bízza annak eldöntését, hogy mely területen jártas tanácsadó bevonására van szüksége (pl. jogi szakértelemmel, pénzügyi vagy a közbeszerzés tárgya szerinti szakmai ismeretekkel bíró tanácsadóra).

A közösségi források felosztásához a megfelelö szintủ szakértelemmel rendelkező szakértői apparátus kialakítása és múködtetése nagyban javíthatja a döntések, a forráskihelyezések megalapozottságát. Ennek az igénynek jogszabályi rögzítése és érvényesítése a jövőben mindenképpen indokoltnak tủnik.

\section{A jogorvoslati rendszer szabályozása}

A közösségi forrásokhoz kapcsolódó hazai (eljárási) szabályozás egyik legsúlyosabb hiányossága a jogorvoslati rendszer hiánya.

A Magyar Köztársaság alkotmánya az alapvető jogok és kötelességek című fejezeten belül az 57. § (5) bekezdésében a következőképp rendelkezik: „A Magyar Köztársaságban a törvényben meghatározottak szerint mindenki jogorvoslattal élhet az olyan bírósági, közigazgatási és más hatósági döntés ellen, amely a jogát vagy jogos érdekét sérti." A jogorvoslati jogot - a jogviták ésszerủ időn belüli elbírálásának érdekében, azzal arányosan - csupán a jelenlévő országgyủlési képviselők kétharmadának szavazatával elfogadott törvény korlátozhatja.

$\mathrm{Az}$ államigazgatási eljárásról szóló 1957. évi IV. törvény hatálya alá tartozó ügyekben még a rendszerváltozást megelözően is biztositott volt a jogorvoslati lehetőség. (A nagyobb baj inkább az volt, hogy az Áe. hatálya alá nem tartozó ún. kvázi államigazgatási szervek is lehetőséget kaptak az életviszonyokba történő beavatkozásra mindenféle jogi szabályozás és kontroll nélkül.) A jogorvoslathoz való jog csupán a bírósági út igénybevétele során szenvedett sérelmet. Az ötvenes években ugyan néhány ügycsoportban biztositott volt a bírósághoz való fordulás joga, azonban ebben az időszakban az állami és politikai hatalomnak olyan mértékủ koncentrációja következett be, amely lehetetlenné tette a végrehajtó szervek tevékenysége feletti bírói kontrollt (Kengyel 2003). 1957 és 1989 között az államigazgatási határozatok felülvizsgálatát az 1957. évi IV. törvény korlátozott körben lehetóvé tette. A 63/1981. (XII. 5.) MT rendelet már 23 ügycsoportban tételesen felsorolta a bíróság által felülvizsgálható határozatokat. Ugyanakkor a jogrendszerböl 1989-ig hiányoztak az intézményes garanciák, így a jogalkotás bármikor szükíthette, vagy tágíthatta a bírósági utat. Hiába ruházta fel az alkotmány a bíróságokat az igazságszolgáltatás monopóliumával, amikor egy minisztertanácsi rendelet is elegendỏ volt ahhoz, hogy meghatározott jogvitákat a bírósági útról ideiglenesen vagy véglegesen elvonjon, és annak elbírálására egy más szervet jogosítson fel.

A jelenleg is hatályos szabályozás irányába az első lépést az 1989. évi XXXI. törvény tette meg, amely az alkotmányban rögzítette azt, hogy a bíróság ellenőrzi a közigazgatási határozatok törvényességét. Ezt követően a 32/1990. (XII. 22.) alkotmánybírósági határozat megsemmisítette a 63/1981. (XII. 5.) MT rendeletet és az 1957. évi 
IV törvény 72. § (1) bekezdését, a kormányt pedig rövid határidő kitüzése mellett felhívta arra, hogy megfelelő törvényjavaslatot terjesszen az országgyülés elé. Ezek után született meg az 1991. évi XXVI. törvény a bírósági határozatok felülvizsgálatának kiterjesztéséről, melyet a közelmúltban hatályba lépett $A$ közigazgatási hatósági eljárás és szolgáltatás általónos szabályairól szóló 2004. évi CXL. törvény helyezett hatályon kívül, természetesen a bírósági út korlátozása nélkül.

A 2004-2006 közötti időszakban a közösségi forrásokhoz kapcsolódó szabályozás a jogorvoslati jog érvényesítése tekintetében - részben hasonló, részben rosszabb a rendszerváltást megelőző korszak jogi szabályozásához és gyakorlatához képest. A vonatkozó jogszabályok - egy kivételtől eltekintve - egyáltalán nem ismerték a jogorvoslat fogalmát és használatának lehetőségét. E tekintetben hasonló helyzet alakult ki, mint a kvázi államigazgatási szervek kontroll nélküli tevékenységét illetően.

A jogorvoslat, illetve a jogorvoslati jog igénybevétele szorosan összefügg a közösségi források felett valamilyen módon rendelkezni, dönteni jogosult szervezetek státuszával. Ha egy ROP közreműködő szervezet hozza meg - esetleg téves, megalapozatlan - döntését, az ellen semmilyen jogorvoslati joggal nem lehet élni. Ezek a közremúködő szervezetek ugyanis Kht.ék, az az nem közigazgatási szervek. Az alkotmány - és a kapcsolódó jogszabályok - csak a közigazgatási szervek határozata elleni jogorvoslati lehetőséget biztosítják. Egy Kht. döntése ellen - szóljon az közcélról és akár milliárdos közpénzröl - nem lehet jogorvoslatot érvényesíteni. $\mathrm{Az}$ ilyen lehetséges eset a jogállamban gondolkodó jogalkotót és jogalkalmazót egyaránt felkészületlenül éri, és teljesen védtelen, valamint kiszolgáltatott helyzetet teremt az érintett fél számára is.

Más a helyzet, ha a döntést az Irányító Hatóság hozza. Az intézményrendszer vizsgálata során bemutatott érvekből egyértelmủen következik, hogy az irányító hatóságok központi közigazgatási szervnek minösülnek. Ugyanakkor alkotmányunk lehetővé teszi a közigazgatási határozatok elleni jogorvoslatot, így egy irányitó hatóság (pl. elutasító) döntése ellen irányuló jogorvoslati kérelem esetén az illetékes bíróság minden bizonnyal megállapitaná hatáskörét és eljárna az ügyben.

A Strukturális Alapok forrásaihoz kötődően egyetlen egy jogszabály jelentett kivételt, amely biztosította - a teljesen evidensnek tünő - jogorvoslat lehetóségét. Ez a jogszabály $A$ mezőgazdasági és vidékfejlesztési támogatásokhoz és egyéb intézkedésekhez kapcsolódó eljárás egyes kérdéseiról és az ezzel összefüggö törvénymódositásokról szóló 2003. évi LXXIII. törvény. A jogszabály ugyan kivette a pályázati eljárás rendezését az államigazgatási eljárás általános szabályai alól azzal az indokkal, hogy az elbírálás összetett folyamata nem teszi lehetővé a törvény által elöírt rövid elintézési határidők betartását. Ugyanakkor a Mezőgazdasági és Vidékfejlesztési Hivatal elutasító döntésével szemben a pályázó írásban az MVH elnökéhez címzett kifogást terjeszthetett elö a döntés kézhezvételétől számított tizenöt napon belül. Az MVH elnöke a kifogást a benyújtástól számított harminc napon belül bírálta el. Az MVH elnökének döntése ellen további jogorvoslatnak helye nem volt, de a pályázó elỏtt nyitva állt a bírósági út igénybevételének lehetősége ${ }^{1}$. 
A jogorvoslati lehetőséget egyedül biztositó rendelkezést is megszüntette a 2005. évi CLVIII. törvény, amely hatályon kívül helyezte a pályázati rendszerre vonatkozó követelményeket és eljárást megállapító rendelkezések túlnyomó többségét. Ennek következtében az az egyetlen minimális jogállami követelményeket teljesitő jogszabály is megszủnt létezni, amely a jogorvoslati lehetőséget valamilyen formában biztositotta.

A jogorvoslati rendszer kialakításában történő állásfoglalás azért sem kerülhető meg, mert a 2007-2013 közötti programozási időszakban - nemzeti forrásokkal együtt - hozzávetôleg 8000 milliárd forint elosztása jogi és megfelelö társadalmi kontroll nélkül nehezen képzelhető el.

Vélhetően ezt az igényt igyekezett akceptálni a 2007-2013 időszakra vonatkozó jogi szabályozás, mely megteremtette a panasz intézményét, azonban sajátos módon ezt nem az eljárási szabályok között intézményesítette (16/2006 [XII. 28.] MeHVMPM rendelet), hanem az általános szabályokat tartalmazó 255/2006. (XII. 8.) kormányrendeletben rendezte. A jogorvoslat választott formájával természetesen nem ez a legnagyobb probléma. Ismeretes, hogy a jelenlegi jogi szabályozás alapján bizonyos összeghatárok figyelembe vétele mellett - az NFÜ hagyja jóvá a projektjavaslatokról szóló döntést. (Ezt a jogot egymilliárd Ft alatti projektjavaslatok esetén delegálhatja a közremúködő szervezetre, ez viszont nem változtat azon, hogy a közremủködő szervezet az NFÜ jogkörében jár el.)

A panasz elbírálása „első fokon” az NFÜ jogkörébe tartozik, vagyis ugyanaz a szervezet illetékes, amely - alapesetben - a jóváhagyó dontést hozza. Az összeférhetetlenséget az a szabály kívánja enyhíteni, amely elöŕja, hogy aki a jóváhagyásban részt vett, az nem vehet részt a panasz elbírálásában.

„Másodfokon" biztosított az ún. felülvizsgálat lehetósége, melyben a döntésre jogosult a fejlesztéspolitikáért felelős miniszter. Ez a jogalkotói megoldás annyiban jelent sajátosságot az egész magyar jogrendszeren belül, hogy - a kormányrendelet hatályba lépése óta eltelt fél évben - nem neveztek ki fejlesztéspolitikáért felelös minisztert. Ez azt jelenti, hogy a „másodfokú” jogorvoslat esetén nem létezik olyan szerv, amely jogosult lenne a felülvizsgálati ügyekben eljárni. Jelen sorok írásának időpontjában csupán fejlesztéspolitikáért felelős kormánybiztos létezik, aki egy személyben és legmagasabb szinten felelős az NFÜ irányításáért ${ }^{2}$ (irányítja az NFƯ elnökének tevékenységét).

Amennyiben a fejlesztéspolitikai kormánybiztost azonos hatáskörrel rendelkezö fejlesztéspolitikáért felelós miniszter váltja fel, ez a jogorvoslat jogállami típusú fórumrendszerének kialakítása tekintetében továbbra sem jelent lényegi változást. Ennek oka, hogy - de facto - az NSRK (ÚMFT) döntései tekintetében nem vagy nehezen bizonyíthatóan létezik jogorvoslati fórumrendszer. A döntési jog, illetve a jogorvoslat telepítés szintje a jelenlegi szabályozás alapján a következö:

- projektjavaslat jóváhagyása: NFÜ;

- döntés a panaszról: NFÜ; 
- döntés a felülvizsgálat tárgyában: egyelőre nincs, de vélhetően az NFÜ elnökét irányító miniszter;

A jelenlegi kormánybiztos, illetve a leendő miniszter tevékenysége oly szorosan kötődik az NFÜ mindennapi tevékenyégéhez, hogy ténylegesen nem tekinthetö önálló, különálló szintnek, fórumnak.

A szabályozás nem tesz emlitést sem arról, hogy a felülvizsgálat eredményeként született döntés ellen további jogorvoslatnak nincs helye (ez az alkotmány szerint kétharmados törvényt igényel), sem arról, hogy a döntés ellen bírósághoz lehet fordulni. A hallgatás - jogállami körülmények között - semmiképpen nem jelenthet korlátozást, ami azt jelentheti, hogy a bírói út lehetősége adott.

A jogorvoslat szabályozásának jelenlegi rendje meglehetősen távol áll a jogállami értékektől és követelményektől, ami önmagában is a rendszer újragondolását indokolja.

\section{Összegzés}

Az uniós források elosztását illető intézmény- és eljárásrendszer számos bizonytalansága és olykor alkotmányossági aggályokat is felvető kérdései mellett talán egyetlen biztos pont látszik körvonalazódni, ez pedig a bizonytalanság, alakíthatóság az egységes európai gyakorlat hiányával írható körül.

$\mathrm{Az}$ intézményrendszer esetén még az Unió egészét tekintve sem léteznek kőbe vésett normák és egységes szabályozási, szervezeti rendszerek. Hazánk esetében a teljesen centralizált modelltől történő elmozdulás remélhetőleg középtávon a tényleges decentralizált rendszer kialakitásában tér nyugvópontra. Ez egyúttal azt is jelenti, hogy a területi szintủ államigazgatás szerepének, funkcióinak újragondolása nem várathat túlságosan sokáig magára. A reformelképzelések megvalósítása során egyértelmüen meg kell határozni a közösségi források felhasználásában szerepet játszó intézményrendszer területi államigazgatásban betöltött helyét, szerepét.

Megfelelő eljárásjogi szabályok kialakításának hiányában a létesítése pillanatában a legjobbnak vélt szervezetrendszer sem képes céljainak, feladatainak eredményes és hatékony ellátására. Az eljárási szabályoknak egyformán eleget kell tenniük a demokratikus jogállami müködés követelményeinek és a hatékony, racionális forráselosztáshoz és felhasználáshoz füzödő igényeknek. Jelen pillanatban - a tapasztalatok szerint - sem a jogi szabályozáson alapuló, sem pedig a jogi szabályozást mellőző eljárási gyakorlat nem, illetve nem maradéktalanul teljesíti ezeket a követelményeket.

A problémák reflektorfénybe állítása, a különböző javaslatok megfogalmazása talán elősegíti a közösségi források eredményesebb, méltányosabb elosztását, felhasználását, ami vélhetően az egész magyar társadalom közös érdeke.

\section{Jegyzetek}

${ }^{1}$ A törvény akkori indoklása szerint: „Mivel a pályázati eljárás nem tartozik az államigazgatási eljárás hatálya alá, ezért a pályázatok esetében az Áe. által elöirt jogorvoslatok sem alkalmazhatóak, de az ügyfél részére abból a célból, hogy alkotmányos jogai ne sérüljenek, mindenképpen biztosítani kell a Hivatal 
Az európai uniós forrásokhoz kapcsolódó eljárásrend hazai jogi szabályozásának problémái. Tér és Társadalom 21. évf. 2007/4. 73-94. p.

elutasító döntésével szemben jogorvoslati lehetöséget. Pályázatok esetében a kifogás jelenti a jogorvoslati lehetőséget a pályázó számára. A kifogás elöterjesztésére az általános szabályoknak megfelelóen 15 napos határidỏ áll az ügyfél rendelkezésére, melyet írásban, az MVH elnökéhez címezve kell benyújtani, és azt a benyúijástól számított 30 napon belül el kell bírálni. Az MVH elnỏkének döntése ellen további jogorvoslatnak nincs helye, az ügyfél ezt követően az ügyben már csak bírósághoz fordulhat."

A kormánybiztost közvetlenül a miniszterelnök irányítja, az NFÜ-t (az NFÜ elnökét) a kormánybiztos. Az NFÜ-n belül elvileg a forráselosztáshoz kapcsolódó döntési jogkör polarizlódhatna az egyes Irányító Hatóságok között, ha azok önálló jogi személyiséggel rendelkeznének, tehát jogi értelemben léteznének. Jogi értelemben azonban nem léteznek, önálló döntési jogosítványuk nincs, amit jelez a 255/2006. (XII. 8.) kormányrendelet $7 . \S$ (4) bekezdése, amely felsorolja azokat a tárgyköröket, amelyekben az NFÜ az IH-ák - 1083/2006 EK rendelet 60. cikkében meghatározott - feladatait látja el, azok nevében jár el. Jogi értelemben tehát egyetlen IH, az NFÜ létezik. A döntés - jogilag - a kormánybiztos, végsö soron a miniszterelnök kezében összpontosul. Ez a fajta hatalmi koncentráció - mely a tervezésben is megjelenik - a rendszerváltást megelőző időszak döntési mechanizmusára emlékeztet.

\section{Irodalom}

Ádảm A. (2004) A közjogi szerzödésekröl. - Jura. 1. 5-17. o.

Cassimati, A.A. (2003) The regional reform in Greece. Department of Government University of Manchaster, Manchaster.

Árva Zs. (2005) Spanyol autonóm közösségek negyedszázada. - Mezö 1.-Wiener Gy. (szerk.) Regionalizmus és önkormányzatiság. Gondolat - DTE ÁJK, Budapest. 93-111. o.

Bekanntmachung von Richtlinien zur Förderung von Unternehmensgründungen im Rahmen von EXTSTSEED. (2004) Bundesministerium für Bildung und Forschung, Bonn.

Berényi S. (1998) Az államigazgatási eljárảsi kódex felülvizsgálata. - Önkormányzat. 3. 24-31. o.

COR (2004) Strenghtenig regional and local democracy in the European Union.

Forman B. (2003) Az Európai Unió strukturális és elöcsatlakozási alapjai. Interpress, Budapest.

Forman B. (2004) A visegrádi országok Nemzeti Fejlesztési Tervei. - Falu Város Régió. 5. 32-47. o.

Gyapay D. (2002) Olaszország. Press Publica, Budapest.

Horváth Gy. (2001) Regionális támogatások az Európai Unióban. Osiris, Budapest.

Horváth M.T. (2005) A közigazgatási szerződések szabályozási koncepciója. - Magyar Közigazgatás. 3. 142-147.0.

Illés D.-Illés I. (2004) Az EU strukturális politikảja módositásảnak forgatókönyvei, az egyes tagállamok álláspontjai. NFH, Budapest.

Jobbágy V. (2001) A strukturális alapok menedzsmentje az EU 15-ökben. - Falu Város Régió. 9. 29-32. o.

Huotari, J. (2001) Finnország. Press Publica, Budapest.

Kardos J.-Simándi I. (2002) Európai politikai rendszerek. Osiris, Budapest.

Kengyel M. (2003) Magyar polgári eljárásjog. Osiris, Budapest.

Lörincz L. (szerk.) (1999) Eljárási jog a közigazgatásban. Unió, Budapest.

Molnár B. (2006) A Strukturális Alapok menedzsmentje az Európai Unió tagállamaiban. Kézirat, MTA RKK DTI, Pécs.

Mónus L. (1997) Egy törvényhely viszontagságai. - Magyar Közigazgatás. Április. 255-256. o.

Mező I. (2005) Az olasz regionális állam kialakulásának és müködésének vázlatos áttekintése. - Mező I.Wiener Gy. (szerk.) Regionalizmus és önkormányzatiság. Gondolat - DTE ÁJK, Budapest. 131-156. o.

Pálné Kovács I. (2005a) A Nemzeti Stratégiai Referenciakeret (2007-2013) koncepcionális megalapozása. $\mathrm{NFH}$, Budapest.

Pálné Kovács I. (2005b) A politikai régió pro és kontra. - Mezö 1.-Wiener Gy. (szerk.) Regionalizmus és önkormányzatiság. Gondolat - DTE ÁJK, Budapest. 22-29. o.

Petrik F. (2005) A közigazgatási aktus alakváltozása, a közszerzödés. - Magyar Közigazgatás. 5. 267-275. o.

Pintér A. (2001) Görögország. Press Publica, Budapest.

Radnóczy Zs. (2004) Támogatások az Európai Unióban. A közösségi támogatások jogalapja, az összeegveztethetöség és a jogvédelem kérdése. Akadémiai Kiadó, Budapest.

ROP Irányító Hatóság Múködési Kézikönyve. Budapest.

ROP Közremüködő Szervezetek Müködési Kézikönyve. Budapest.

Schwartz, B. (1976) Administrative Law. Little Broward Company, Boston - Toronto.

Szamel L.--Ivancsics L. (1996) Az államigazgatási eljárás. JPTE, Pécs.

Új partnerség a kohézió érdekében. (2004) Harmadik Kohéziós Jelentés.

Zeiler J. (2000) Hollandia. Press Publica, Budapest. 


\section{PROBLEMS OF THE HUNGARIAN LEGAL REGULATION OF THE PROCEDURES RELATING TO THE EUROPEAN UNION RESOURCES}

\section{ISTVÁN FINTA}

The study is written on the procedural issues related the Structural Funds, in whose creation and application a double practice can be observed in Hungary: some of the procedures are regulated in ministerial decrees, while the rest of the rules are created neglecting the legal regulations, in the form of internal organisational rules. It goes without question that the implementation of any objective with state development intentions - be they the most honest objectives - is much simpler and more effective if the legal regulations are neglected; however, this questions the necessity of a democratic legal state and promotes the advantages of a state structure of different type.

The study sees three alternative solutions for the legal regulation of the procedures:

- Extension of the effect of the acts on administrative procedures (state administration procedures act, act on public procurement),

- Sui generis regulation,

- The integration of the procedures already existing and the ones to be created into a legal regulation in effect.

The essay pays a special attention to those elements of the tender support system that require amendments or a further regulation, and also to those questions that are important for the operation of the constitutional state, such as of the legal regulation of the appeal system, the inadequate application of the principle of publicity and its incomplete integration into the legal regulation of the procedures related to the distribution of the community resources. 